\title{
Transformation of South Caucasus Countries During 25 Years of Independence
}

\author{
Larisa Korganashvili \\ Doctor of Economic Sciences, Professor Ivane Javakhishvili Tbilisi State University, Tbilisi, Georgia \\ Natavan Mammadova \\ Phd in Economics Baku Business University, Baku, Republic of Azerbaijan
}

Pikria Tsotskolauri

Doctor of Economics, Associate professor St. Andrew the First-Called Georgian University of the Patriarchate of Georgia

Lela Kochlamazashvili

Doctor of Economics, Professor Georgian Technical University, Tbilisi, Georgia

\begin{abstract}
More than 25 years have passed since countries of the South Caucasus gained independence. During this time, they underwent a serious transformation, their geopolitical and economic significance, as well as the relationship with the outside world has changed. The countries of the South Caucasus are small and their role in the world economy is negligible. However, because of the important geopolitical location, they attract the attention of many major powers and thus external factors play an important role in their development. The purpose of this work is to study the peculiarities of the transition of countries of the South Caucasus from the socialist system to the capitalist, to identify the problems of this transformation and to show the ways of their solution, and to determine the influence of regional and non-regional countries on the economic development of these countries.The paper analyzes the trends in the economic development of the countries of the South Caucasus, the features of their transformation, the degree of economic interdependence and the possibilities for deepening cooperation, shows the structural features and international competitiveness of national economies, the prospects for economic development of these countries, taking into account external factors, the possibilities of globalization and modern geo-economic conditions.
\end{abstract}

Keywords: the countries of the South Caucasus, transformation, economic development, foreign trade, investment, competitiveness.

\section{Introduction}

Over 25 years ago, the South Caucasus Countries (SCCs) - Armenia, Azerbaijan and Georgia declared independence and transferred to a new stage of their historical development. The post-Soviet transformation of the SCCs was found to be complex and rather painful. On the one hand, the disruption of production ties of the former union republics led to a deep economic crisis, while, on the other, as a result of the contradictory attitude of major powers to this region, the South Caucasus became an area of three interethnic conflicts having developed into open military confrontations.

The SCCs are small countries and therefore their role in the world economy is insignificant. However, they occupy an important geopolitical and geostrategic position in the given region. They are located at the border of the All-European space of security. Here the interests of Russia and the U.S.A, also of other regional and non-regional states intersect. The SCCs offer rather important advantages of a transit hub of the Central Asia, and this can either contribute to or interfere with the development of communication between the West and the East. The Republic of Azerbaijan possesses reserves 
of oil and gas, for transportation of which the pipelines running through Georgia are used. These pipelines are an alternative to the Russian pipelines and accordingly Russia is not interested in the availability of competitors. Neighboring Russia has a special influence on the development of the SCCs.

The purpose of this work is to study the trends and processes of the SCCs transformation under conditions of independent statehood. It is oriented toüards the consideration of economic problems, however, in the current stage, the economy and politics are so interrelated that cannot be separated. Correspondingly, to achieve the goal of the problem under study, definite attention is being paid to political issues as well.

\section{Transformation of the South Caucasus countries under conditions of state independece}

Every country aspires to the common goals of the civilization development, but goes towards them following its own path, based on its national interests, cultural habits, national mentality, etc. Accordingly, the sovereign development of the SCCs also has its peculiarities that go with their common soviet past. After the breakup of the Soviet Union, each SCC had to cope with the problem of "triple transition" [Korganashvili, 2014]: 1) from the Soviet totalitarian state to democracy; 2) from the centrally-planned economy and total state owned properties to the market economy and private property; 3) from a republic in the composition of the large state to a sovereign republic with a small economy. The world knew no analogue of transition from the socialist subsystem to the capitalist one and, naturally, such transformation was connected with enormous difficulties, the processes developed spontaneously and, generally, by the trial-and-error method.

Transformation of the centrally-planned economy began as early as the years of "perestroika" (restructuring) of the Soviet Union, when the first steps in the direction of a market economy (spring of 1985-August of 1991) were made under Gorbachev. The perestroika period can be conditionally divided into 2 stages: the first stage targeted on the perfection of the existing system of social relations (1985-1988) and the second targeted on the development of market relations (19881991). However, instead of positive results, the perestroika has further aggravated the Soviet Union's economy and the country had to transit to the rationing of products: for a number of essential goods vouchers were introduced, wages in individual enterprises started to be paid out by goods produced therein and the workers had to sell those goods themselves. The crisis situation in the country led to the break-up of the USSR and to the emergence of 15 new sovereign states. The formation of national economies of these states was accompanied with disengagement of the former union republics. The sovereign states had actually to depend only on their natural and accumulated competitive advantages determined by the Soviet heritage. As the sovereign SSCs had different launch opportunities (economy structure, availability of raw material resources, food, degree of industrial development, infrastructure, etc.) and as a result of this, they faced different difficulties of the transformation processes. Their relationships were also problematic. After the breakup of the common Soviet economic space, they were challenged with the problem of forming national economic complexes and the optimal sectoral make-up. Deep economic differences, especially in the supply with raw material resources, resulted in the difference of strategic and current interests of the FSU republics.

During the $70 \mathrm{~s}-80 \mathrm{~s}$ of the $20^{\text {th }}$ century, the former South Caucasus Soviet republics occupied the middle position according to the degree of economic and industrial development among the Soviet republics, but lagged behind the western and central republics and regions of the USSR. The leading hand in their economy belongs to the manufacturing industries of Group A and construction, and the share of agriculture in GDP did not exceed $10-15 \%$. On the whole, the region was characterized by a low degree of the economy and industry complexity, up to $55-65 \%$ of its material resources being formed at the expense of import and export. The winemaking, fruit and vegetable and tobacco production were based on own raw material in all the three republics, petrochemistry and light industry in Azerbaijan, electrical industry in Armenia. The share of population with a monthly income below RUB 75 constituted in Azerbaijan $29.7 \%$, while the monthly money wages - RUB 194.6; in Georgia these figures made 6.5\% and RUB 214.0 respectively, while in Armenia - 5.4\% and RUB 241.3. Out of the SCCs, Georgia had the lowest natural population growth index per 1,000 of population $-8.6 \%$; in Armenia it made $17.4 \%$ and in Azerbaijan - 20.2\% (table 1). 
Table 1: Some social indicators of Union Republics in 1989

\begin{tabular}{|c|c|c|c|}
\hline Union Republic & $\begin{array}{l}\text { Share of population with a } \\
\text { monthly income below } 75 \\
\text { RUB* in } \%\end{array}$ & $\begin{array}{l}\text { Average monthly wages and } \\
\text { salaries, RUB }\end{array}$ & $\begin{array}{l}\text { Natural increase, births per } \\
1,000 \text { population }\end{array}$ \\
\hline Tajikistan & 45,1 & 206,9 & 32,6 \\
\hline Uzbekistan & 34,1 & 215,4 & 27,6 \\
\hline Azerbaijan & 29,7 & 194,6 & 20,2 \\
\hline Turkmenistan & 26,9 & 243,7 & 27,2 \\
\hline Kyrgyzstan & 24,8 & 219,2 & 22,3 \\
\hline Kazakhstan & 10,0 & 265,4 & 14,0 \\
\hline Georgia & 6,5 & 214,0 & 8,6 \\
\hline Moldova & 6,1 & 233,0 & 8,0 \\
\hline Armenia & 5,4 & 241,3 & 17,4 \\
\hline Russia & 3,2 & 296,8 & 2,2 \\
\hline Ukraine & 2,7 & 248,4 & 0,6 \\
\hline Belorussia & 1,5 & 264,5 & 3,2 \\
\hline Lithuania & 1,2 & 283,3 & 4,6 \\
\hline Latvia & 0,9 & 290,9 & 1,1 \\
\hline Estonia & 0,6 & 340,7 & 1,8 \\
\hline USSR & 7,7 & 274,6 & 6,5 \\
\hline \multicolumn{4}{|c|}{$\begin{array}{l}\text { * Beginning from 1985, the subsistence wage in the USSR was on monthly average of RUB } 75 . \\
\text { Source: } 1 \text {. National economy of the USSR in } 1990 \text {. State Statistics Service. M.: Finances \& Statistics, } 1991 . \\
\text { C. } 38,89,115 . \\
\text { 2. Social-economic Development of Post-Soviet Countries: Overall Results of the Twenty-year Period. - M.: } \\
\text { IE RAS, 2012, p. } 16\end{array}$} \\
\hline
\end{tabular}

Soviet republics were closely interrelated and their participation in the inter-republican exchange was different to some extent. In 1989 , the inter-republican turnover constituted $55 \%$ of the total volume of republican trade relations, $45 \%$ accounting for foreign economic relations. Almost half of the inter-republican exchange was the share of the RSFSR. The share of Armenia constituted $1.7 \%$ of import and $1.5 \%$ of export, that of Azerbaijan $-1.8 \%$ and $2.9 \%$, of Georgia- $2.3 \%$ and $2.5 \%$, respectively (table. 2).

Table 2: Import and export of products by republics in 1989 at the actual intra-Union prices

\begin{tabular}{|c|c|c|c|c|c|c|c|c|}
\hline & \multicolumn{2}{|l|}{ Import } & \multicolumn{2}{|l|}{ Including in \% } & \multicolumn{2}{|l|}{ Export } & \multicolumn{2}{|l|}{ Including in \% } \\
\hline Republic & $\begin{array}{l}\text { Total, billion } \\
\text { RUB }\end{array}$ & $\%$ & $\begin{array}{l}\text { Inter-republican } \\
\text { exchange }\end{array}$ & Import & $\begin{array}{l}\text { Total, } \\
\text { billion RUB }\end{array}$ & $\%$ & $\begin{array}{l}\text { Inter-republican } \\
\text { exchange }\end{array}$ & Export \\
\hline RSFSR & 144,3 & 50.7 & 49,0 & 51,0 & 109,6 & 45.2 & 68,5 & 31,5 \\
\hline Ukraine & 54,5 & 19.1 & 73,3 & 26,7 & 48,1 & 19.9 & 84,2 & 15,8 \\
\hline Belorussia & 19,4 & 6.8 & 76,7 & 23,3 & 20,3 & 8.4 & 90,2 & 9,9 \\
\hline Kazakhstan & 17,6 & 6.2 & 82,9 & 17,1 & 9,1 & 3.8 & 90,2 & 9,8 \\
\hline Uzbekistan & 14,2 & 5.0 & 85,1 & 14,9 & 10,2 & 4.2 & 84,0 & 16,0 \\
\hline Lithuania & 7,4 & 2.6 & 78,8 & 21,2 & 6,3 & 2.6 & 92,4 & 7,6 \\
\hline Moldova & 6,6 & 2.3 & 78,5 & 21,5 & 5,5 & 2.3 & 95,1 & 4,9 \\
\hline Georgia & 6,5 & 2.3 & 75,6 & 24,4 & 6,1 & 2.5 & 93,9 & 6,1 \\
\hline Latvia & 6,0 & 2.1 & 75,0 & 25,0 & 5,4 & 2.2 & 93,2 & 6,8 \\
\hline Azerbaijan & 5,2 & 1.8 & 73,0 & 27,0 & 7,1 & 2.9 & 93,4 & 6,6 \\
\hline Armenia & 4,9 & 1.7 & 78,3 & 21,7 & 3,7 & 1.5 & 97,6 & 2,4 \\
\hline Kyrgyzstan & 4,3 & 1.5 & 78,3 & 21,7 & 2,6 & 1.1 & 98,1 & 1,9 \\
\hline Tajikistan & 3,9 & 1.4 & 82,7 & 17,3 & 2,5 & 1.0 & 86,2 & 13,8 \\
\hline Estonia & 3,8 & 1.3 & 84,6 & 15,4 & 3,1 & 1.3 & 92,9 & 7,1 \\
\hline Turkmenistan & 3,3 & 1.2 & 82,3 & 17,7 & 2,7 & 1.1 & 91,0 & 9,0 \\
\hline Total & 284,7 & 100.0 & 62,9 & 37,1 & 242,3 & 100.0 & 78,8 & 21,2 \\
\hline
\end{tabular}


After the break-up of the USSR, the SCCs found themselves in a catastrophic economic recession. The most complicated period in their history were the years 1991-1995, when the fundamental changes of the political and economic structures were taking place, the rights and freedoms of citizens were being legislatively recognized, while the major changes in the social sphere were at the development stage. Georgia and Azerbaijan found themselves in an especially hard situation, where volumes of the lowest GDP constituted USD 2,514 (1994) and 3,052 (1995) mln respectively or 32.4 и $34.4 \%$ from the 1990 level. In Armenia, the situation was comparatively better: the lowest index was observed in 1993 and constituted $53.2 \%$ (Figure 1).

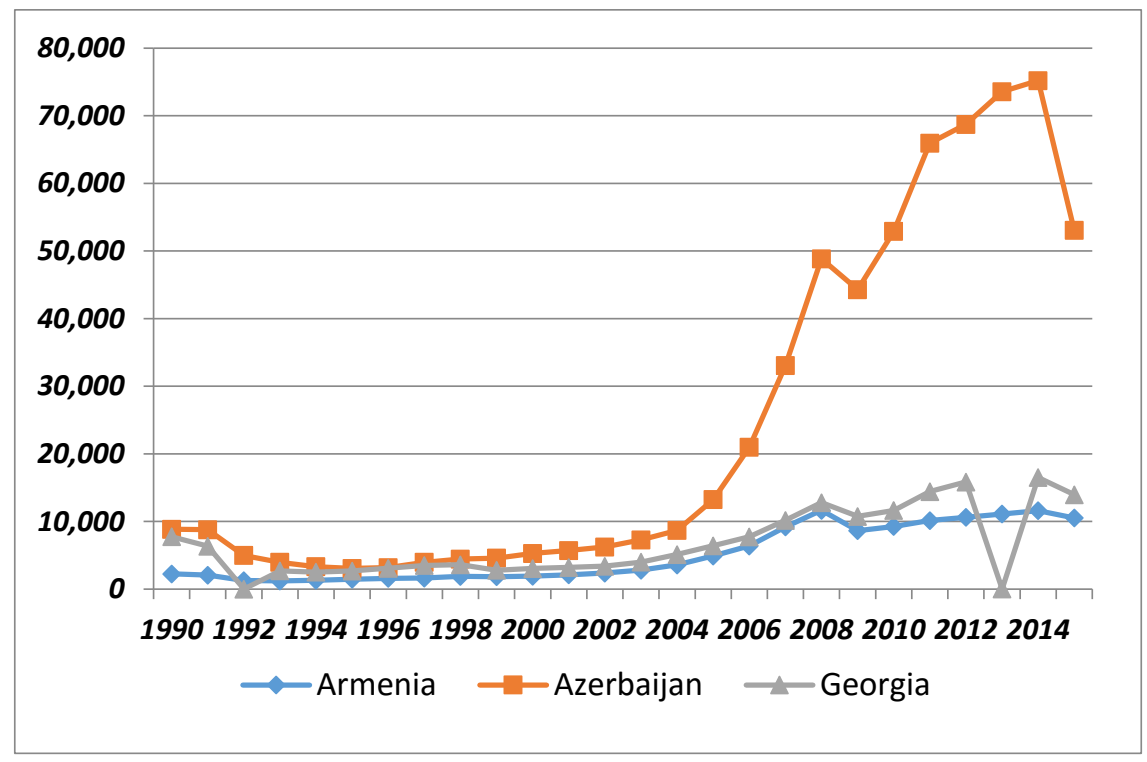

Figure 1: GDP of the South Caucasus Countries, current US\$ mIn Source:

http://data.worldbank.org/indicator/NY.GDP.MKTP.CD?view=chart

Due to hard socio-economic position of the SCCs, anticrisis programs of macroeconomic stabilization and systems transformation had been developed, under which the radical changes were initiated: transformation of the fiscal and monetary and credit sphere, privatization of the state property, reforming of the health care, education, social sphere, etc. The transformation processes with a transition to market relations in all the South Caucasus countries proceeded under the recommendations of the IMF, on the basis of the liberal economic policy, the requirements of which are:

- Liberalization of prices and tariffs of goods and services;

- Maximum reduction of the budget deficit and curtailment of social programs;

- Cancellation of the practice of purposeful and "cheap" credits;

- Creation and development of a financial market;

- Stage-by-stage privatization of state property and maximal reduction of the State's participation in the economic life of the country;

- Cancellation of state support of industry, etc.

The SCCs almost concurrently accepted the conditions and standards proposed by the IMF. As a result of their realization, they were able to overcome the existing economic crisis and achieve the economic growth. However, the SCCs used to 
develop at different rates. The highest growth rate of GDP was observed in Azerbaijan in 2006 (34\%), in Armenia - in 2003 (145) and in Georgia - in 2007 (12.3\%) (Figure 2).

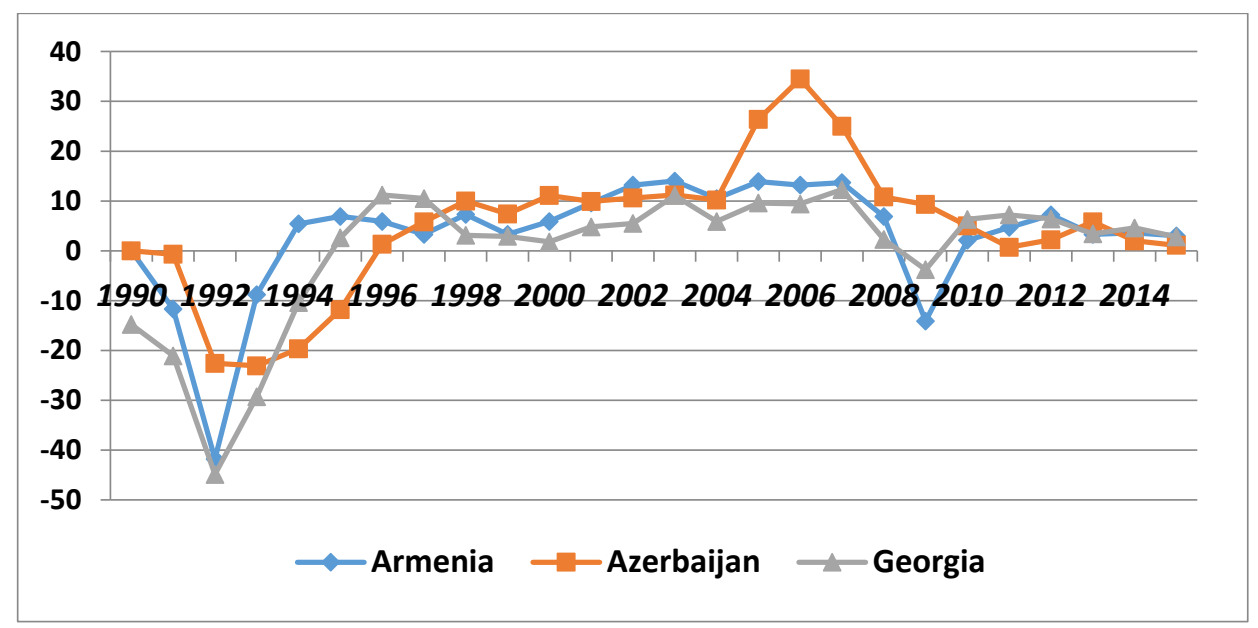

Figure 2: GDP growth in the South Caucasian Countries, annual \%Source:

http://data.worldbank.org/indicator/NY.GDP.MKTP.KD.ZG?locations=AM\&view=chart

In 2015, the highest GDP per capita was in Azerbaijan - USD 5,497, followed by Georgia - USD 3,757 and Armenia - USD 3,489. It should be noted that the GDP per capita levels in 2014 were higher, constituting USD 7,886; 4,430 and 3,862 respectively (Figure 3). The situation can be explained by a reduction of GDPs in all the three SCCs: in Armenia from USD 11,610 to $10,529 \mathrm{mln}$, in Azerbaijan - from USD 75, 198 to 53,047 $\mathrm{mln}$, in Georgia - from USD 16,509 to 13,965 mln [World Bank].

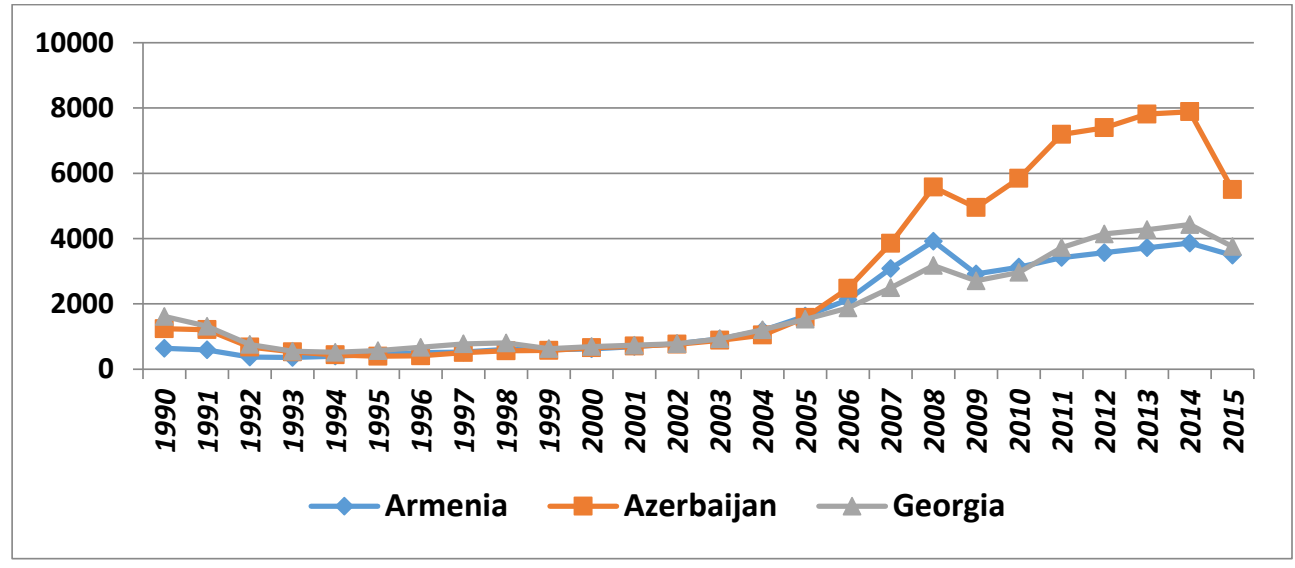

Figure 3: GDP per capita in the South Caucasian Countries, current USD Source:

http://data.worldbank.org/indicator/NY.GDP.PCAP.CD

The economy of the SCCs differs by the structure and is being constantly transformed. In 1990, in Armenia the share of agriculture in the country's GDP constituted $17 \%$, of industry $-52 \%$ and of services $-31 \%$. In Azerbaijan these figures 
constituted 29, 33 и 38\% respectively, in Georgia - 32, 33 and 35\%. In 2015, the GDP structure of the SCCs was as follows: Armenia - 19, 29 и 52\%; Azerbaijan - 7, 37 and 56\%, Georgia - 9, 25 and $66 \%$. On the whole, the high share of agriculture is characteristic for Armenia, in $1994-45 \%$, of industry - for Azerbaijan, the maximum was attained in $2008-70 \%$, of service - for Georgia, maximum share in 2008-2010 - 69\% [World Bank].

Foreign trade plays an important role in the economic development of the SCCs. In 2015, the share of export of goods and services in the GDP constituted 30\% in Armenia, 38\% - in Azerbaijan and $45 \%$ in Georgia (Figure 4), while the share of imports of goods and services - 42, 35 and 65\% respectively (Figure 5). In 2015, the export of goods from Armenia constituted USD 1,487 mln, while their import - USD 3,254 $\mathrm{mln}$, commercial services exports - USD 1,549 $\mathrm{mln}$; in Azerbaijan, these figures made for goods - USD 14,500 and 9,400 mln, for services - USD 4,423 and 8,553 mln, in Georgia: for goods - 2.204 and USD 7,724 mln: for goods; USD 3,066, mln and USD 1,614 $\mathrm{mln}$ - for services.

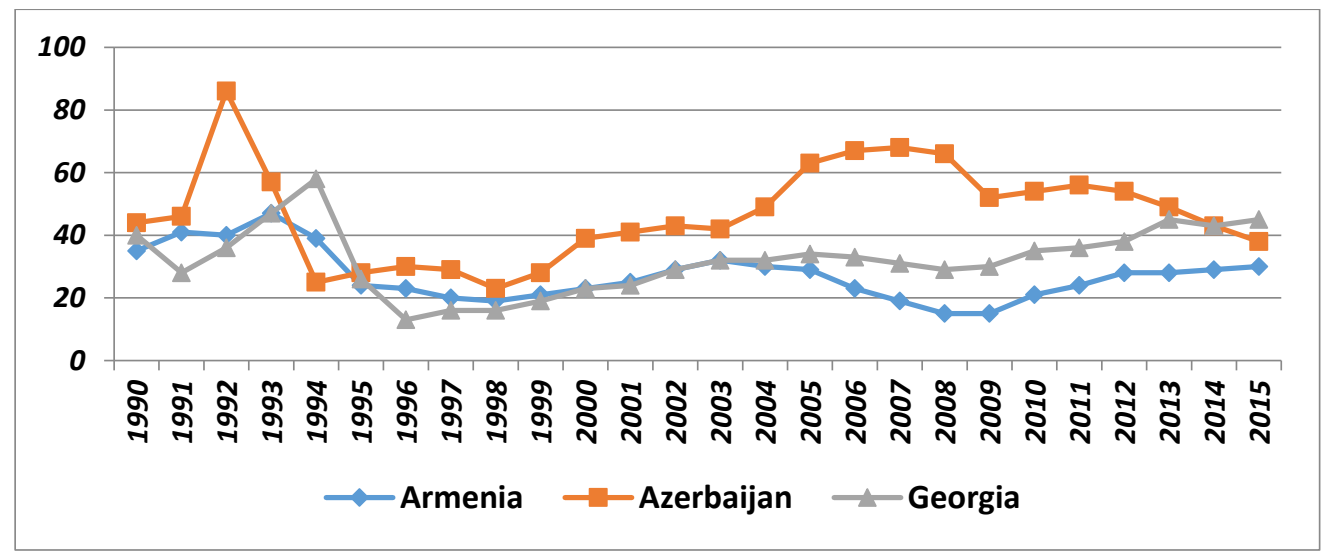

Figure 4. Exports of goods and services of South Caucasian Countries, \% of GDP Source: The World Bank. Exports of goods and services. http://data.worldbank.org/indicator/NE.EXP.GNFS.ZS?view=chart

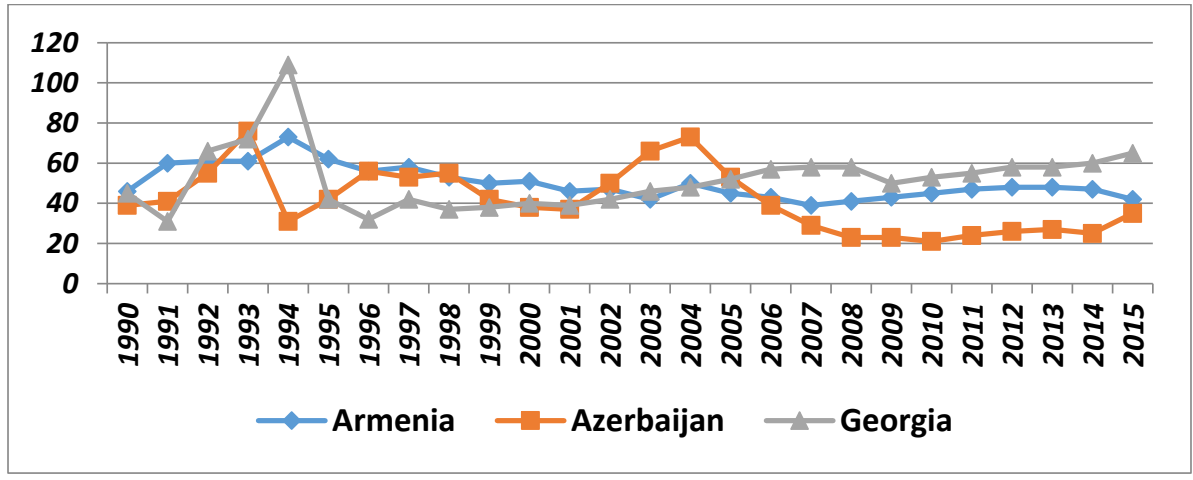

Figure 5: Imports of goods and services in the South Caucasus Countries, \% of GDP Source: The World Bank. Imports of goods and services. http://data.worldbank.org/indicator/NE.IMP.GNFS.ZS?view=chart

A major part in the transformation processes of the SCCs belongs to foreign direct investments. In 2015, the volume of foreign investments in Armenia totaled USD 178,452,920, in Azerbaijan - USD 4,047,630,000 and in Georgia - USD 
$1,571,048,770$. The investment activity started in 1995-1996 and differs by countries and years. In Armenia such activity is observed in year 2008 (USD 943,733,059), in Azerbaijan - in 2012 (USD 5,293,250,000), in Georgia - in 2007 (USD $1,877,615,756)$ [World Bank].

The effectiveness of national economies is determined by its competitiveness on the world markets. According to the Global Competitiveness Index 2016-2017 rankings, Armenia is ranked the $79^{\text {th }}$, Azerbaijan - the $37^{\text {th }}$ and Georgia - the $59^{\text {th }}$ [WEF, 2016]. The World Economic Forum estimates the SCCs by the stage of development as follows: Armenia and Georgia belong to stage 2: Efficiency-driven economies; Azerbaijan is in Transition from stage 1 (Factor-driven economies) to stage 2 (Efficiency-driven economies); Armenia has the best showing by the $6^{\text {th }}$ pillar: Goods market efficiency (ranked the $45^{\text {th }}$, scored 4.6), Azerbaijan - by the $7^{\text {th }}$ pillar: Labor market efficiency $\left(26^{\text {th }}, 4.8\right)$, Georgia - by the $3^{\text {rd }}$ pillar: Macroeconomic environment $\left(40^{\text {th }}, 5.2\right)$. The worst showing have: Armenia - by the 10 th pillar: Market size $\left(120^{\text {th }}, 2.7\right)$, Azerbaijan - by the $8^{\text {th }}$ pillar: Financial market development $\left(97^{\text {th }}, 3.5\right)$, and Georgia - by the $12^{\text {th }}$ pillar: Innovation $\left(116^{\text {th }}, 2.8\right)$ (Figure 6$)$ [WEF, 2016].

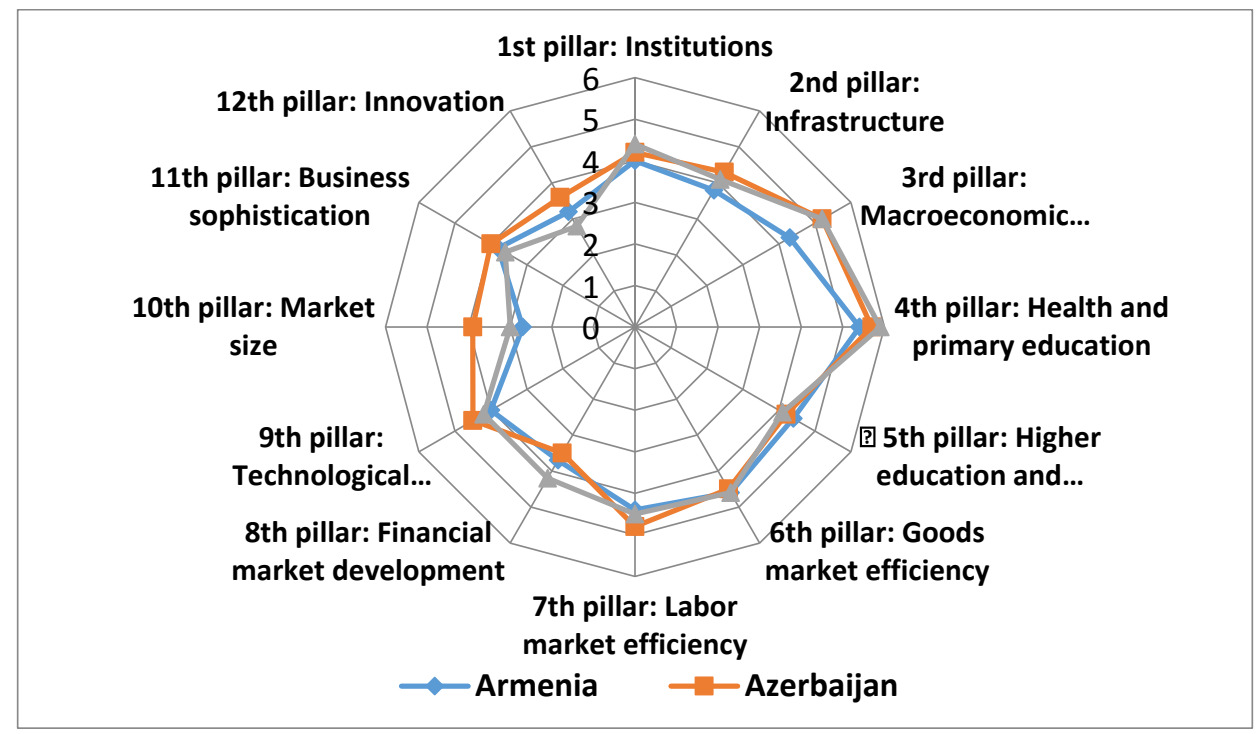

Figure 6. Global Competitiveness Index of the South Caucasus Countries Source: World Economic Forum. The Global Competitiveness Report 2012-2013. Geneva. pp. 100-101, 106-107, 184-185. http://www3.weforum.org/docs/GCR20162017/05FullReport/TheGlobalCompetitivenessReport2016-2017_FINAL.pdf

The transformation processes in the SCCs can be characterized by the Bertelsmann Stiftung's Transformation Index (BTI). The BTI analyzes and evaluates whether and how developing countries and countries in transition are steering social change toward democracy and a market economy. Guided by a standardized codebook, country experts assess the extent to which a total of 17 criteria have been met for each of the 129 countries [BTI. 2016]. The BTI consists of two components: Status Index and Management Index. In its turn, the Status Index consists of two variables. The first reflects the degree/status of advancement of the countries toward democracy (Democracy Status), the second - towards a market economy. The Democracy Status is determined on the basis of five criteria: Stateness, Political Participation, Rule of Law, Stability of Democratic Institutions, Political and Social Integration. The economic transformation analysis criteria are: Level of Socioeconomic Development, Organization of the Market and Competition, Currency and Price Stability, Private Property, Welfare Regime, Economic Performance, Sustainability and Competition. 
The Management Index ranks the countries according to their leadership's political management performance. It consists of five criteria: Level of Difficulty, Steering Capability, Resource Efficiency, Consensus-Building and International Cooperation. According to the data of Table 3 below concerning the SCCs, the transformation processes are developed most successfully in Georgia. It has the best ratings by both the Status Index and the Management Index. At that, the ratings of these indexes in Georgia have improved, while in Azerbaijan and Armenia they have worsened. In 2016, by the Status Index Georgia ranks the 45th, Armenia - the $64^{\text {th }}$, Azerbaijan - the $95^{\text {th }}$; by the Management Index they are ranked as the $39^{\text {th }}, 84^{\text {th }}$ and the $103^{\text {rd }}$ respectively (Table 3 ).

Table 3: The Bertelsmann's Transformation Index (BTI) for the South

Caucasus countries, 2012-2016

\begin{tabular}{|c|c|c|c|c|c|c|c|c|c|}
\hline & \multicolumn{3}{|c|}{ Armenia } & \multicolumn{3}{|c|}{ Azerbaijan } & \multicolumn{3}{|c|}{ Georgia } \\
\hline & 2016 & 2014 & 2012 & 2016 & 2014 & 2012 & 2016 & 2014 & 2012 \\
\hline Ranking Status Index & 64 & 62 & 65 & 95 & 88 & 84 & 45 & 48 & 57 \\
\hline S | Status Index & 5.56 & 5.71 & 5.59 & 4.44 & 4.71 & 4.85 & 6.31 & 6.16 & 5.88 \\
\hline SI | Democracy Status & 5.23 & 5.35 & 5.25 & 3.48 & 3.92 & 4.02 & 6.70 & 6.50 & 6.15 \\
\hline Q1 | Stateness & 8.8 & 8.5 & 8.5 & 7.0 & 7.5 & 7.5 & 6.3 & 6.5 & 6.3 \\
\hline Q2 | Political Participation & 4.5 & 4.5 & 4.0 & 2.8 & 3.0 & 3.3 & 8.5 & 8.0 & 7.5 \\
\hline Q3 | Rule of Law & 4.3 & 4.8 & 4.8 & 3.0 & 3.8 & 4.0 & 6.5 & 6.0 & 6.0 \\
\hline $\begin{array}{l}\text { Q4 Stability of Democratic } \\
\text { Institutions }\end{array}$ & 3.0 & 3.0 & 3.0 & 2.0 & 2.0 & 2.0 & 7.0 & 7.0 & 6.5 \\
\hline $\begin{array}{l}\text { Q5 | Political and Social } \\
\text { Integration }\end{array}$ & 5.7 & 6.0 & 6.0 & 2.7 & 3.3 & 3.3 & 5.3 & 5.0 & 4.5 \\
\hline SII | Market Economy Status & 5.89 & 6.07 & 5.93 & 5.39 & 5.50 & 5.68 & 5.93 & 5.82 & 5.61 \\
\hline $\begin{array}{l}\text { Q6 | Level of Socioeconomic } \\
\text { Development }\end{array}$ & 4.0 & 4.0 & 4.0 & 5.0 & 5.0 & 5.0 & 4.0 & 4.0 & 4.0 \\
\hline $\begin{array}{l}\text { Q7 | Organization of the Market } \\
\text { and Competition }\end{array}$ & 6.3 & 6.5 & 6.5 & 4.3 & 4.5 & 4.8 & 7.0 & 6.8 & 7.3 \\
\hline \begin{tabular}{l|l} 
Q8 & Currency and Price Stability
\end{tabular} & 7.0 & 7.0 & 7.0 & 7.0 & 6.5 & 6.5 & 7.0 & 7.0 & 6.5 \\
\hline Q9 | Private Property & 8.0 & 8.0 & 8.0 & 5.0 & 5.5 & 5.5 & 6.5 & 6.5 & 7.0 \\
\hline Q10 | Welfare Regime & 6.0 & 5.5 & 5.5 & 6.0 & 6.0 & 6.0 & 5.5 & 4.5 & 4.0 \\
\hline Q11 | Economic Performance & 5.0 & 6.0 & 5.0 & 6.0 & 6.0 & 7.0 & 6.0 & 6.0 & 5.0 \\
\hline Q12 $\mid$ Sustainability & 5.0 & 5.5 & 5.5 & 4.5 & 5.0 & 5.0 & 5.5 & 6.0 & 5.5 \\
\hline Ranking Management Index & 84 & 69 & 73 & 103 & 99 & 98 & 39 & 41 & 53 \\
\hline M | Management Index & 4.29 & 4.84 & 4.70 & 3.72 & 3.95 & 4.00 & 5.72 & 5.78 & 5.38 \\
\hline Q13 | Level of Difficulty & 4.3 & 4.2 & 4.6 & 4.7 & 4.9 & 4.7 & 4.8 & 5.5 & 5.5 \\
\hline MII | Management Performance & 4.92 & 5.55 & 5.35 & 4.22 & 4.45 & 4.53 & 6.47 & 6.43 & 5.98 \\
\hline Q14 | Steering Capability & 4.3 & 4.7 & 4.7 & 4.3 & 4.3 & 4.3 & 5.7 & 6.0 & 5.7 \\
\hline Q15 | Resource Efficiency & 4.3 & 5.3 & 5.3 & 3.3 & 3.3 & 3.7 & 6.7 & 6.0 & 6.0 \\
\hline Q16 | Consensus-Building & 5.0 & 5.2 & 4.4 & 3.2 & 3.8 & 3.8 & 6.2 & 6.4 & 5.6 \\
\hline Q17 | International Cooperation & 6.0 & 7.0 & 7.0 & 6.0 & 6.3 & 6.3 & 7.3 & 7.3 & 6.7 \\
\hline
\end{tabular}

Source: http://www.bti-project.org/en/home/

The essential improvement of business environment and economic freedom contribute to the economic development of the SCCs. According to ease of doing business in the 2017 rating, Armenia is ranked the $38^{\text {th }}$, Azerbaijan - the $65^{\text {th }}$, and Georgia - the $16^{\text {th }}$ among 190 countries of the world [World Bank, DB, 2017]. In the 2017 rankings of the level of economic freedom, Armenia is ranked the $33^{\text {rd }}$, Azerbaijan - the $68^{\text {th }}$, and Georgia - the $13^{\text {th }}$ among 186 countries. Armenia and Georgia belong to mostly free countries, and Azerbaijan - to moderately free countries [IEF, 2017]. Although Azerbaijan has the worst showings by Doing Business and Index of Economic Freedom, but, as indicated above, it outstrips by economic development Armenia and Georgia. Openness to global trade and investment, supported by some improvements in regulatory efficiency, has aided Azerbaijan's transition to a more market-based economic system. Continued transformation and restructuring are needed to capitalize on the well-educated labor force and broaden the production base. Economic growth has been driven mainly by development of the energy sector. Challenges to diversification and 
sustainable growth remain substantial. Deeper systemic reforms are critically needed to advance and institutionalize economic freedom more firmly. Despite some progress, property rights are weak, and corruption remains widespread. State involvement in banking is still excessive, and lingering financial instability adds to uncertainty [IEF, 2017, Azerbaijan].

Considerable diversification of Armenia's economic base has increased economic dynamism. Broad simplification of business procedures has facilitated regulatory efficiency. After years of expansionary fiscal policies, efforts have been made to limit the cost of government through more prudent management of public finance. More reforms are needed for Armenia to enhance judicial independence and government transparency. Despite progress in tackling corruption, particularly in the tax and customs administrations, close relationships within political and business circles raise concerns about cronyism and undue influence [IEF, 2017, Armenia].

Georgia's government has maintained strong momentum in liberalizing economic activity while taking steps to restore fiscal discipline. Public debt and budget deficits remain under control. Open-market policies, supported by competitively low tax rates and regulatory efficiency, have facilitated flows of trade and investment. Large-scale privatization has advanced, and anticorruption efforts have yielded some notable results. With monetary stability and the overall soundness of fiscal health relatively well maintained, Georgia has enjoyed macroeconomic resilience. Nonetheless, deeper and more rapid institutional reforms to enhance judicial independence and effectiveness remain critical to ensuring further dynamic and lasting economic development [IEF, 2017, Georgia].

On the whole, the transformation processes in the SCCs met the requirements proposed by international financial and economic organizations to the introduction of market mechanisms and democratic transformations. Despite the fact that the economic and political transformations proceeded at different rate of intensity and were accompanied with a whole number of shortcomings and errors, nevertheless the radical transition to market relations using shock therapy has yielded a positive result. In the current stage of development, the SCCs proceed with the course of transformation, consisting now in the strengthening and perfection of the existing mechanisms.

The path directed toward the strengthening of sovereignty requires from each state a complex dynamic estimation and is coupled with different upheavals of the world politics. Thereupon, in considering the issue of further development of the South Caucasus countries, the globalization challenges, the necessity of integration into the world and regional economic structures, the possibilities of protection of national interests should be prioritized. The degree of impact on the world of global integration is measured by the index of globalization. According to the KOF Index of Globalization 2015, Georgia is ranked the $63^{\text {rd }}$, Armenia - the $83^{\text {rd }}$, and Azerbaijan - the $87^{\text {th }}$; by the Economic Globalization, they are ranked the $19^{\text {th }}$, the $64^{\text {th }}$ and the $73^{\text {rd }}$ respectively; by the Social Globalization - the $77^{\text {th }}$, the $111^{\text {th }}$ and the $95^{\text {th }}$ respectively; by the Political Globalization - the $142^{\text {nd }}$, the $94^{\text {th }}$ and $123^{\text {rd }}[K O F, 2015]$. As can be seen from these data, the South Caucasus countries are involved in the globalization processes at various rates. It should, however, be kept in mind that further development of these countries is impossible without participation in the regional integration, which at the expense of synergy effects and scale can ensure the acceleration of the economic growth, the enhancement of competitiveness, etc. At that, the following problems should also be solved:

- Undetermined regional conflicts, turning at times to open military confrontations;

- Creating international strife and the climate of mistrust;

- Unsatisfactory level of democratization and insufficient level of socio-economic development;

- Not impartial interest of the international community and non-regional forces in the countries of the region.

The solution of these problems and a complex task of attaining a balance of the national interests of the SCCs are possible only on the basis of a reasonable compromise, searching for such non-confrontational strategies of cooperation, which can ensure their peaceful coexistence and socio-economic development. All subjects of the Caucasus should keep in mind that the progress and development in the Caucasus region are greatly dependent on their peaceful coexistence and economic cooperation. 


\section{Conclusion}

During a quarter of a century of state independence radical reforms characterized by an accelerated liquidation of old economic structures and a transition to market relations have been carried out in the South Caucasus countries. However, these transformations failed to yield a sufficient effect and the South Caucasus continues to be one of the most problematic regions of the modern world. This is a territory of three interethnic conflicts and the place of confrontation of many large states of the world, as a result of which the SCCs experience serious political, economic and other problems. For the solution of these problems a reasonable compromise between all the subjects of the Caucasus region attitude as well as the understanding of the necessity of peaceful coexistence are primarily needed. It should be remembered that only under conditions of peace the progress and sustainable economic development can be achieved.

\section{References}

[1] BTI 2016. Georgia Country Report. https://www.bti-project.org/en/reports/country-reports/detail/itc/GEO/

[2] BTI 2016. Armenia Country Report. https://www.bti-project.org/en/reports/country-reports/detail/itc/ARM/

[3] BTI 2016. Azerbaijan Country Report. https://www.bti-project.org/en/reports/country-reports/detail/itc/AZE/

[4] KOF Index of Globalization 2015.

http://globalization.kof.ethz.ch/media/filer_public/2015/03/04/rankings_2015.pdf

[5] Korganashvili L. (2014) Socio-economic transformations in South Caucasus countries: realities and prospects. The Economic Transformation of the Cities and Regions in the Post-communists Countries. Edited by Cezary Madry and Denis Dirin.Proceedings. Wydawnictwo Naukowe. Poznan, Poland, pp.117-128

[6] National economy of the USSR in 1990. State Statistics Service. M.: Finances \& Statistics, 1991

[7] Social-economic Development of Post-Soviet Countries: Overall Results of the Twenty-year Period. - M.: IE RAS, 2012

[8] The Bertelsmann Stiftung's Transformation Index (BTI). https://www.bti-project.org/en/index/

[9] The Index of Economic Freedom (IEF) (2017). Country Rankings. http://www.heritage.org/index/ranking

[10] The Index of Economic Freedom (IEF) ( 2017). Country. Armenia.http://www.heritage.org/index/country/Armenia

[11] The Index of Economic Freedom (IEF) (2017). Country. Azerbaijan. http://www.heritage.org/index/country/azerbaijan

[12] The Index of Economic Freedom (IEF) (2017). Country. Georgia. http://www.heritage.org/index/country/georgia

[13] The World Bank (WB). Exports of goods and services. http://data.worldbank.org/indicator/NE.EXP.GNFS.ZS?view=chart

[14] The World Bank (WB). Foreign direct investment http://data.worldbank.org/indicator/BX.KLT.DINV.CD.WD?view=chart

[15] The World Bank (WB). Imports of goods and services. http://data.worldbank.org/indicator/NE.IMP.GNFS.ZS?view=chart

[16] The World Trade Organization (WTO). Trade profile. Georgia. http://stat.wto.org/CountryProfiles/GE_e.htm

[17] The World Trade Organization (WTO). Trade profile. Armenia. http://stat.wto.org/CountryProfiles/AM_e.htm

[18] The World Trade Organization (WTO). Trade profile. Azerbaijan. http://stat.wto.org/CountryProfiles/AZ_e.htm

[19] World Economic Forum (WEF) (2016). (The Global Competitiveness Report 2012-2013. Geneva. pp. 100101, 106-107, 184-185. http://www3.weforum.org/docs/GCR20162017/05FullReport/TheGlobalCompetitivenessReport2016-2017 FINAL.pdf 